\title{
SENI TARI UNTUK REMAJA DI LPK “TUNAS HARAPAN” MALENDENG MANADO
}

\author{
Sri Sunarmi \\ Universitas Negeri Manado \\ srisunarmi@unima.ac.id
}

\section{PENDAHULUAN}

\section{Analisis Situasi}

Memperhatikan pendidikan dimasa kini dan masa mendatang dan juga memperhatikan hak setiap Warga Negara Indonesia, agar bisa mendapatkan hak pendidikan. Pendidikan untuk semua (Education for All). Sebuah kalimat pendek yang bermakna bahwa pendidikan amat penting dan harus dilaksanakan bagi seluruh lapisan masyarakat Indonesia.

Berbagai upaya dan kebijakan telah dicetuskan dan dilaksanakan oleh pemerintah melalui bidang pendidikan, namun pada kenyataannya di sekitar kita terutama di Malendeng Perkamil Manado, masih terlihat adanya anakanak dan remaja yang semestinya masih duduk dibangku sekolah saat jam belajar, tetapi mereka berada di tempat yang kurang tepat bagi usia mereka. Mereka ada yang dijalanan sebagai pengemis, penjual koran, bekerja di pasar, dengan kondisi yang memprihatinkan. Mereka adalah anakanak yang kurang beruntung karena orang tua mereka adalah merupakan orang-orang tua yang tidak mampu., atau tingkat ekonomi mereka sangat rendah. Kondisi inilah yang menarik dan perlu untuk dicermati oleh kita semua sebagai masyarakat yang peduli pada pendidikan dan peningkatan sumber daya manusia.

LPK (Lembaga Pendidikan Ketrampilan) "TUNAS HARAPAN" merupakan lembaga Pendidikan dan Ketrampilan yang berupaya untuk membantu pemerintah dalam mengatasi anak-anak yang kurang beruntung yang ada di Manado. Hal ini dilakukan dengan merekrut dan memberikan ketrampilan agar kedepan anak-anak yang kurang beruntung memperoleh layanan pendidikan dan ketrampilan yang memadahi. Sanggar/ LPK "TUNAS HARAPAN" berusaha untuk memberikan beberapa bekal keterampilan kepada anak anak yang kurang beruntung, dengan harapan agar anak-anak yang kurang beruntung nantinya/kelak dikemudian hari mampu bekerja mandiri dan bahkan dapat membuka lapangan kerja secara mandiri. 
Berdasarkan hal tersebut, maka penulis sebagai tenaga pendidik merasa tergugah dan terpanggil serta ingin berpartisipasi dalam menanggulangi permasalahan seperti rendahnya Sumber Daya Manusia, karena kurangnya pendidikan akibat kemiskinan. Sebagai tenaga pendidik dibidang keahlian seni tari tidak salah kalau ikut berperan aktif dalam menyikapi seperti hal tersebut diatas. Barangkali dengan berpartisipasi dengan memberikan bekal pelatihan keterampilan seni tari, maka diharapkan agar para remaja tidak menjadi berkeliaran kesana kemari dan diharapkan juga tidak berbuat yang negatif dan karena sudah mempunyai kesibukan dengan adanya kegiatan pelatihan seni tari tersebut. Selain hal tersebut partisipasi dengan memberikan bekal pelatihan keterampilan seni tari juga diharapkan hidup mereka akan menjadi meningkat. Sehingga dengan kecakapan ketrampilan seni tari akan bermuara pada peningkatan penghasilan serta peningkatan kesejahteraan.

\section{Permasalahan.}

Sebagaimana uraian diatas merupakan gambaran permasalahan yang perlu untuk disikapi oleh siapa saja karena semua anak-anak wajib untuk mendapatkan pendidikan baik secara formal maupun non formal. Juga memperhatikan pendidikan dimasa kini dan masa mendatang dan juga memperhatikan hak setiap Warga Negara Indonesia, agar bisa mendapatkan hak pendidikan .

Pendidikan secara formal bagi anak-anak remaja di Malendeng khususnya tentu sangat memerlukan biaya yang sangat besar. Hal ini dapat dilihat masih adanya anak-anak remaja khususnya di Malendeng Perkamil Manado, yang semestinya masih duduk dibangku sekolah saat jam belajar, tetapi mereka berada di tempat yang kurang tepat bagi usia mereka. Mereka banyak berkeliaran, ada yang dijalanan sebagai, penjual koran, bekerja di pasar, dengan kondisi yang memprihatinkan. Sehingga LPK "TUNAS HARAPAN" di Malendeng Manado telah merekrut mereka, yaitu anak-anak remaja yang merupakan anak dari orang tua yang tidak mampu, yang oleh tidak bisa mengikuti pendidikan secara formal, dan akan diberikan bekal beberapa pendidikan ketrampilan. Namun kegiatan mengenai pelatihan tari yang ada di Sanggar Sekar tersebut, sangat kurang maksimal dilakukan, apalagi hasil kegiatan tersebut juga kurang maksimal.

Berdasarkan hal tersebut diatas, maka penulis sebagai tenaga pendidik dibidang keahlian seni tari tidak salah kalau ikut berperan aktif dan 
berpartisipasi dalam menyikapi seperti hal tersebut diatas, dengan memberikan pelatihan Seni Tari. Dalam hal ini peserta didik diharapkan dapat mengikuti kegiatan ini sehingga diharapkan yang nantinya peserta didik atau anak-anak remaja akan mampu bekerja, berusaha mandiri dan menciptakan lapangan kerja serta memiliki penghasilan tetap serta menjadi bagian dan upaya kita bersama dalam mengentaskan masyarakat dari keterbelakangan dan kemiskinan serta meningkatkan kesejahteraan keluarganya dan kehidupanya.

Artinya, dengan kegiatan pelatihan ketrampilan menari maka mereka akan memiliki ketrampilan menari. Dengan kecakapan ketrampilan tari maka diharapkan akan dapat membuka lapangan kerja secara mandiri dan dapat meningkatkan penghasilan pada peningkatan kesejahteraan bagi mereka. Artinya dengan ketrampilan menari anak-anak remaja yang kurang beruntung akan mempunyai kesibukan latihan dan tidak akan berkeliaran kesana kemari. Namun yang lebih penting lagi bahwa anak-anak remaja diharapkan bisa menghidupi diri sendiri. Hal ini bisa dilakukan pada kegiatan-kegiatan baik secara formal maupun non formal.

\section{Solusi yang ditawarkan}

Kegiatan ini dilakukan untuk mendukung realisasi program kegiatan pengabdian kepada masyarakt pada mitra binaan, yaitu Sanggar/ LPK "TUNAS HARAPAN “ dengan melalui Pelatihan Seni Tari. Metode yang ditawarkan meliputi pembekalan Pelatihan gerak Tari Nusantara dan Pengetahuan tentang Kewirausahaan atau Managemen Pemasaran. Adapun solusi yang akan dicapai melalui kegiatan Pelatihan Seni Tari ini adalah sebagai berikut:

1. LPK (Lembaga Pendidikan Ketrampilan ) "TUNAS HARAPAN" di Manado Memberikan layanan akses pendidikan bagi anak yang kurang beruntung khususnya anak-anak dan remaja kepada anak anak remaja yang kurang beruntung/ anak-anak remaja yang merupakan anak dari orang tua yang tidak mampu. memberikan beberapa bekal keterampilan agar dapat tumbuh dan berkembang secara layak dalam masyarakat.

2. Pelatihan Ketrampilan Seni Tari merupakan salah satu solusi untuk memberikan kegiatan secara positif dengan memberikan bekal, hidup mandiri kepada anak- anak yang kurang beruntung. Dengan membawa anak-anak dan remaja jalanan kedalam suasana proses 
pembelajaran untuk menumbuhkan pengetahuan, sikap dan psikomotornya dengan bentuk back to school.

3. Merubah pola hidup anak-anak remaja jalanan kearah pola hidup yang bisa terencana. Melalui Pelatihan Ketrampilan Seni Tari dapat menjadikan anak-anak kurang beruntung, kelak bisa menghidupi diri sendiri

Melalui kegiatan Pelatihan Seni Tari ini adalah untuk mendukung realisasi program kegiatan pengabdian kepada masyarakt pada mitra binaan, yaitu Sanggar/ LPK "TUNAS HARAPAN “ dengan melalui Pelatihan Seni Tari. Metode yang ditawarkan meliputi pembekalan Pelatihan gerak Tari dan Pengetahuan tentang Kewirausahaan atau Managemen Pemasaran.

\section{Target Luaran.}

Target Luaran yang dihasilkan sesuai dengan fokus rencana program pelatihan adalah:

1. Mitra anggota Sanggar diharapkan melalui program pelatihan ini memiliki mental kewirausahaan yang potensial.

2. Mitra Binaan akan menghasilkan produk penari Seni Tari yang layak dipentaskan sebagai sebagai penari atau sebagai pelatih tari yang dapat ditawarka di kalangan masyarakat,diacara atau dievent- event kesenian.baik secara formal maupun non formal.

3. Memiliki peningkatan ketrampilan dalam pengembangan kreassi seni tari nusantara

4. Ketika masa binaan telah berakhir, diharapkan dalam masyarakat kelak dapat meningkatkan ekonomi keluarga sehingga memperoleh kesejahteraan yang lebih baik, terutama tidak menggantungkan hidupnya kepada orang lain, karena memiliki kepercayaan diri, dan ketrampilannya dapat mendatangkan penghasilan. Kedepan diharapkan dapat menciptakan lapangan pekerjaan bagi warga masyarakat yang membutuhkan.

5. Dengan memilki bekal keahlian ketrampilan Seni Tari para peserta pelatihan Pengabdian Masyarakat ini kelak bila telah usai mengikuti Pelatihan dapat mengembangkan ketrampilan tersebut, sehingga dapat menciptakan lapangan pekerjaan sendiri. Bila dibina secara terus menerus diharapkan akan membantu program pemerintah dalam mengentaskan pendidikan serta kemiskinan, Sehingga 
terwujud

kesejahteraan

masyarakat.

Dalam target luaran digambarkan perbedaan kualitas produk hasil warga binaan sebelum pelatihan dan sesudah melewati masa pelatihan. Perbedaan tersebut adalah sebagai berikut:

\section{- Sebelum Pelatihan}

Sebelum pelatihan produk yang dihasilkan oleh Sanggar / LPK "TUNAS HARAPAN" masih adanya anak-anak remaja khususnya di Malendeng Manado, yang semestinya masih duduk dibangku sekolah saat jam belajar, tetapi mereka berada di tempat yang kurang tepat bagi usia mereka. Mereka banyak berkeliaran, ada yang dijalanan sebagai, penjual koran, bekerja di pasar, dengan kondisi yang memprihatinkan.

\section{- Setelah Pelatihan}

Setelah diadakan pelatihan dengan materi pengembangan Tari Nusantara dari sanggar / LPK "TUNAS HARAPAN" di Malendeng Manado memberikan bekal ketrampilan seni tari nusantara, maka anak-anak dan remaja bisa trampil menarikan tari nusantara sebagai produk penari atau instruktur/ pelatih Tari Nusantara yang layak dipentaskan dan dapat ditawarkna di kalangan masyarakat,diacara atau dievent-event kesenian.baik secara formal maupun non formal.
Materi yang digunakan dalam kegiatan ini adalah Tari-Tari Nusantara dan Tari Daerah Setempat. Adapun peralatan yang digunakan adalah Video dengan monitornya, serta menggunakan Tape Recorder beserta kaset-kaset yang berisi rekaman Music Iringan Tari-Tari Nusantara dan Tari Daerah Setempat.
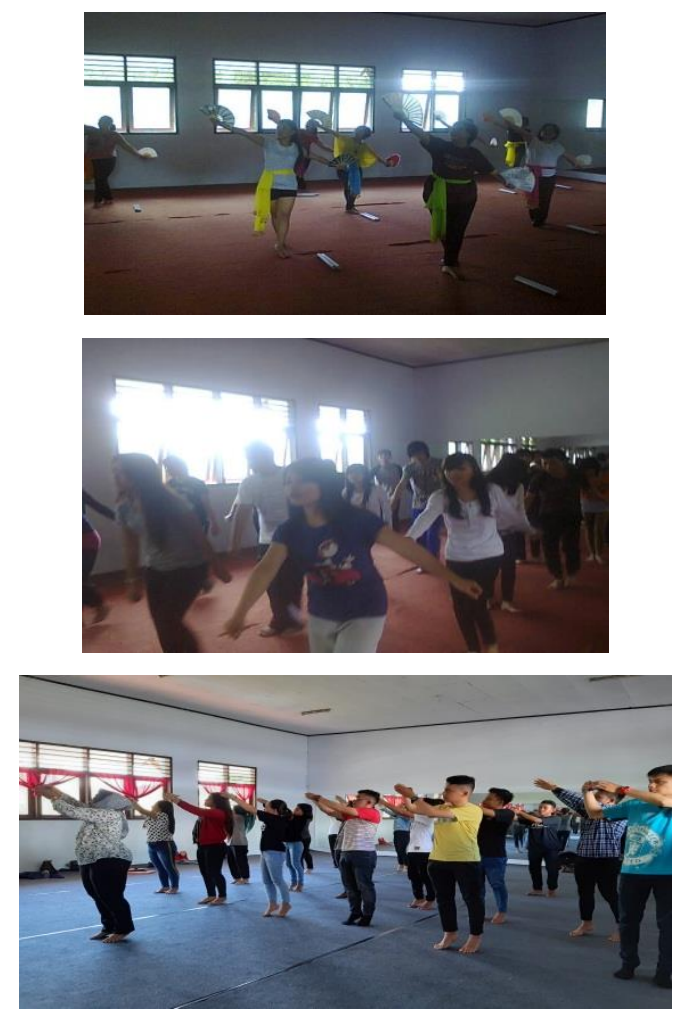

\section{METODE PELAKSANAAN}

Metode yang digunakan dalam pelatihan ini adalah metode Andragogi. Suatu metode belajar mengajar yang menekankan kegiatan praktek $80 \%$ dan 20 $\%$ teori sebagai pengantar wawasan atau persepsi. Metode yang digunakan dalam kegiatan pelatihan seni tari nusantara ini, selain metode bimbingan secara langsung, metode bervariasi juga digunakan dalam 
pelatihan ini. Artinya bimbingan secara berlangsung dengan memberikan ceramah atau penjelasan materi dengan menunjukkan materi dengan diputarkan video hasil rekaman materi. Kemudian instruktur melakukan demonstrasi materi dan diharapkan para peserta akan mengikuti dari belakang serta menirukan. Adapun metode demonstrasi ini akan dilakukan secara berulang-ulang. Kegiatan akan dilakukan pada sore hari yaitu dilaksanakan $1 \mathrm{x}$ dalam satu minggu, yaitu setiap hari sabtu sore.

Kegiatan ini diawali dengan observasi mulai dari lokasi tempat kegiatan diSanggar /LPK "TUNAS HARAPAN" yang jaraknya sekitar $30 \mathrm{Km}$, yaitu di Malendeng Manado untuk mendapatkan data awal. Adapun rencana kegiatan dan langkah-langkah solusi atas permasalahan yang disepakati bersama sebagai berikut:

$\begin{array}{rlr}\text { Langkah I : } & \text { Dari hasil } & \text { Observasi } \\ & \text { diketahui } & \text { fokus } \\ & \text { permasalahan yang paling } \\ & \text { urgent adalah melalui } \\ & \text { pengabdian Masyarakat } \\ & \text { yaitu Pelatihan melalui } \\ & \text { Bimbingan teknis }\end{array}$

Langkah II : Menentukan binaan yang akan diikut sertakan dalam pelatihan, dengan sepengetahuan Pembina yaitu bapak Umar Suryadi, S.Pd.. sebagai penanggung jawab Sanggar

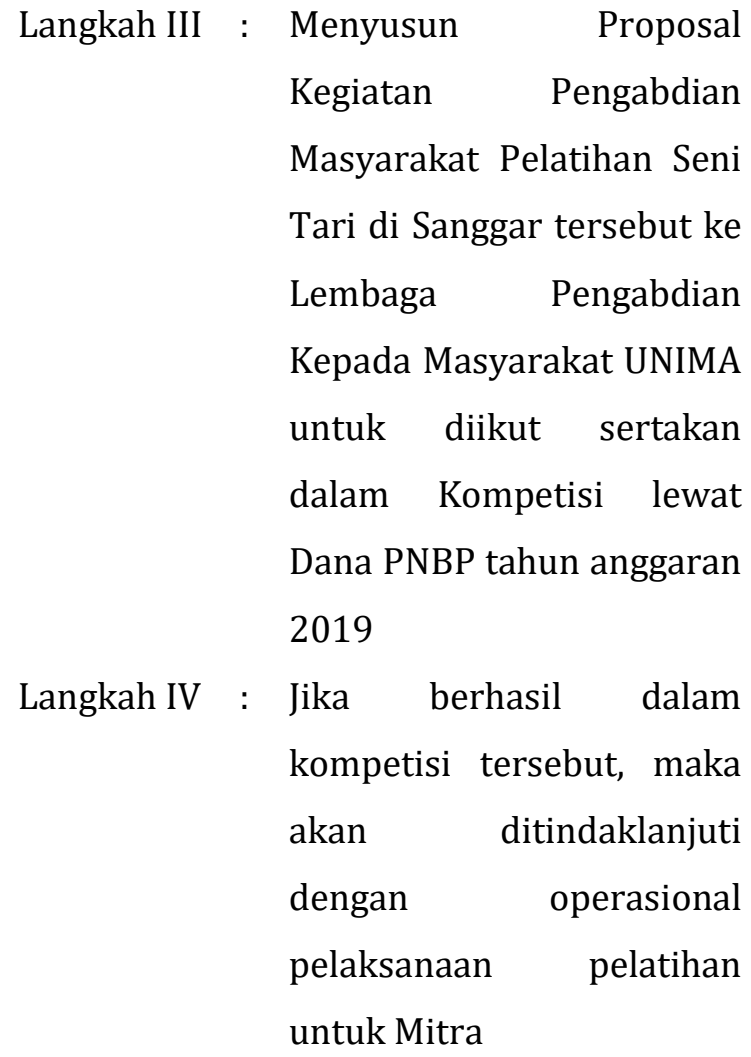

angkah V : Pelaksanaan kegiatan pelatihan tari Nusantara ini, dapat dilakukan dengan baik. Pelaksanaan kegiatan ini dilakukan dengan menggunakan metode bimbingan secara langsung, metode bervariasi juga digunakan dalam kegiatan pelatihan ini. Artinya bahwa kegiatan pelatihan dilakukan dengan bimbingan secara berlangsung dengan memberikan ceramah atau penjelasan materi dengan menunjukkan materi dengan diputarkan video hasil rekaman materi. Kemudian instruktur melakukan demonstrasi atau mempraktekkan materi-materi tari Nusantara tersebut atau memberikan contoh-contoh gerakan demi gerakan tanpa menggunakan musik iringan tari lebih dulu dan kemudian para peserta menirukan 
gerakan demi gerakan yang diberikan dari pelatih atau instruktur secara berulangulang (Drill) tanpa menggunakan musik iringan juga.

Selanjutnya Instruktur memberikan contoh gerak materi tari tari tersebut juga dengan menggunakan musik iringan tari dan dilakukan sedikit demi sedikit atau gerak demi gerak. Yang kemudian para peserta juga mengikuti apa yang dilakukan oleh pelatih atau instruktur dengan sedikit demi sedikit atau gerak demi gerakan dan disertai dengan menggunakan musik iringan tarinya juga. Metode yang demikian tersebut dilakukan secara terus menerus, dan selanjutnya setelah peserta memahami dan hafal gerakan demi gerakan atau vokabuler demi vokabuler masingmasingjenis tarian, dilanjutkan dengan mempraktekan materi dari awal hingga akhir materi, atau materi vokabuler taritari daerah setempat hingga pada akhir vokabuler tari tari modern dan kreasi. Setelah para peserta bisa memahami dan menghafal materi, kemudian dilakukan test atau dicoba para peserta untuk melakukan gerakan tarian yang telah diberikan baik secara kelompok maupun secara perorangan. Secara kelompok kadangkadang dilakukan oleh semua peserta dan kadang - kadang diuji coba untuk mempraktekkan gerakan tarian empatempat orang bergantian. Selain itu juga dicoba untuk melakukan secara perorangan dan bergantian. Selain materi dari instruktur, kegiatan pelatihan ini juga dicoba diberikan tugas untuk mempraktekkan tari nusantara tersebut .

Adapun materi yang disampaikan atau kegiatan yang dilakukan yaitu dengan melakukan diataranya:

1. pelatihan olah tubuh menuju pada gerak-gerak dasar Tari:

2. Pelatihan dan pengenalan bentuk, pola-pola gerak dasar Tari Nusantara

3. Pelatihan dengan mempraktekkan gerak dasar tari Minahasa mewakili tari yang ada di Sulawesi sampai pada polapola gerak dasar tari Papua.

4. Pelatihan mengenai pola-pola lantai atau formasi-formasi yang digunakan,

5. Pengenalan kepekaan musik iringan tari nusantara,

6. Serta pelatihan dan pengenalan tata rias dan busana yang digunakan dalam tari nusantara.

\section{$7 . \quad$ Pelatihan}

\section{Kewirausahaan}

Dalam program Pelatihan ini Mitra Binaan wajib mengikuti Pelatihan sesuai dengan Jadwal yang disepakati yaitu $1 \mathrm{x}$ dalam satu minggu, yaitu setiap hari sabtu. Sehingga ketika pelatihan selesai masih berlaku jadwal pendampingan pasca pelatihan sampai mitra menghasilkan produk yang berkualitas dan layak dipasarkan/ 
dipentaskan/ ditampilkan/ layak memberikan penampilan.

\section{HASIL DAN PEMBAHASAN}

Hasil Kegiatan pelatihan tari ini sesuai dengan jadwal kegiatan yang disusun maka, secara umum kegiatan pelatihan tari melalui kegiatan pengabdian kepada masyarakat ini dapat berjalan dengan baik serta sangat menggembirakan. Hal ini dapat dilihat dari antusias dan semangat peserta pelatihan yang mempunyai rasa keinginan untuk segera trampil menari sangat besar sehingga menimbulkan kebanggaan tersendiri bagi penyelenggara., baik Sanggar atau LPK" TUNAS HARAPAN" maupun dosen'pelaksana kegiatan pengabdian pada masyarakat yang sekaligus sebagai instruktur.

Pengamatan dan evaluasi selama menjalankan kegiatan pelatihan tari ini, masing-masing peserta memperoleh ketrampilan tari atau menari dengan baik , dengan pencapaian scor yang beragam. Artinya, masing-masing peserta mempunyai tingkat ketrampilan bergerak sangat beragam, ada yang memang sudah mahir bergerak tari, namun juga masih ada belum terlalu memahami bergerak tari sesuai capaian, dikarenakan selama ini jarang dilakukan pelatihan secara maksimal sesuai dengan tuntutan estetika. Biasanya mereka latihan hanya sekedar latihan dan hafal sja , serta tidak dilakukan pelatihan secara penjiwaan dalam seni tari.. selain peserta tidak berbakat dengan seni tari juga belum terbiasa untuk latihan bergerak tari yang secara maksimal.

\section{Luaran yang Dicapai}

Pada dasarnya kegiatan pengabdian pada masyarakat berjalan dengan baik dan lancar. Secara umum binaan menyambut baik atas adanya program kegiatan pengabdian pada masyarakat tersebut, karena sangat membantu bagi warga masyarakat binaan lebih khusus bagi anakanak yang kurang beruntung untuk mendapatkan pendidikan, ketrampilan dan pola hidup yang lebih baik serta terencana dengan kegiatan pelatihan ketrampilan tari ini.
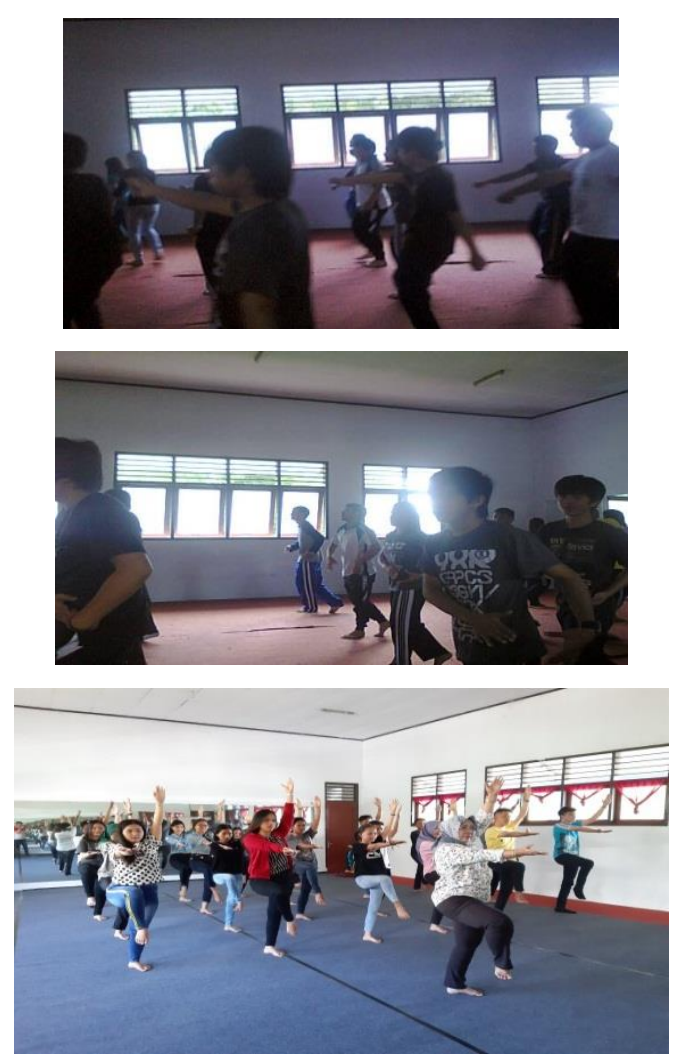

Dengan kegiatan tersebut binaan yang tadinya hanya bisa menari yang tanpa 
dilandasi pemahaman secara etika dan estetika, akhirnya mereka mampu dan trampil dalam melakukan tari nusantara sesuai dengan makna yang ada dalam tarian tersebut. Selain trampil, faham dengan makna estetika tari binaan juga mampu melakukan dan membuka lapangan kerja secara mandiri dengan membuka sanggarsanggar tari serta mampu menjadi instrutur atau pelatih tari dan menjadi penari yang lebih professional.

Hasil pelatihan seni tari ini dapat disimpulkan, bahwa kegiatan pelatihan ini telah berhasil dilaksanakan dengan menggunakan materi garak-grak dasar tari Nusantara yang terdiri dari gerak-gerak dasar tari daerah yang ada di Nusantari Indonesia. Yaitu dimulai gerak dasar tari daerah Sulawesi hingga gerak dasar tari daerah Papua.

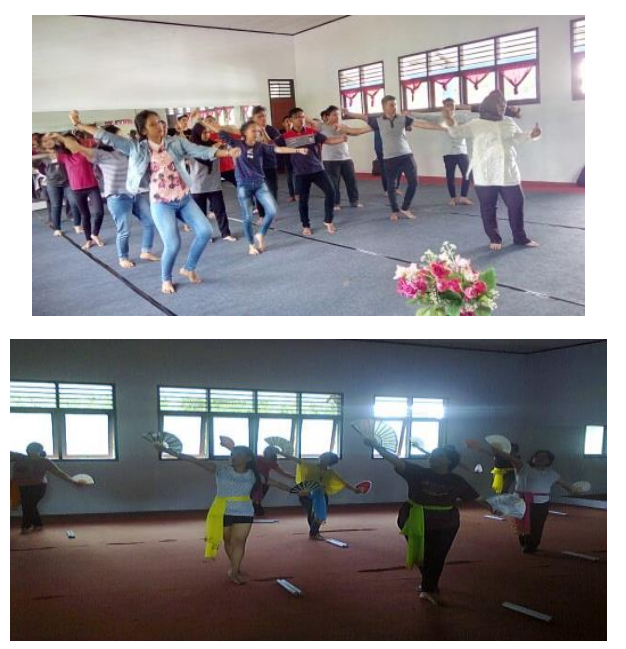

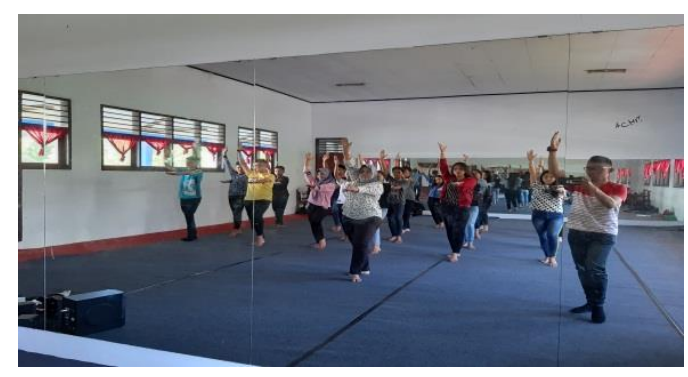

Peserta adalah anak-anak remaja dan anak-anak yang kurang beruntung yang berada di lingkungan binaan sanggar TUNAS HARAPAN Manado. Kegiatan dilaksanakan setiap 1X seminggu, pada hari Sabtu sore jam 15.00. WITA, selama 3 bulan dimulai pada tanggal 13 April hingga tanggal 15 Juli 2019.

Secara umum kegiatan ini disambut baik atas adanya kegiatan pelatihan tari sebagai kegiatan program pengabdian kepada masyarakat semacam ini, karena sangat membantu bagi warga masyarakat lebih khusus bagi anak -anak remaja / anak kurang beruntung untuk mendapatkan pendidikan, ketrampilan dan pola hidup yang lebih terencana

Setelah diadakan pelatihan dengan materi pengembangan Tari Nusantara dari sanggar/LPK "TUNAS HARAPAN" di Malendeng Manado memberikan bekal ketrampilan seni tari nusantara, maka Luaran dari hasil kegiatan tersebut, dihasilkan sesuai dengan fokus rencana program pelatihan, anak-anak dan remaja bisa trampil menarikan tari nusantara sebagai produk penari atau instruktur/ pelatih Tari yang layak dipentaskan dan dapat ditawarkan di kalangan 
masyarakat,diacara atau dievent-event kesenian.baik secara formal maupun non formal. Adapun hasil luaran tersebuat adalah:

1. Mitra anggota Sanggar melalui program pelatihan memiliki mental kewirausahaan yang potensial.

2. Mitra Binaan dapat menghasilkan produk penari Seni Tari Nusantara yang layak dipentaskan sebagai sebagai penari atau sebagai pelatih tari yang dapat ditawarka di kalangan masyarakat,diacara atau dievent-event kesenian.baik secara formal maupun non formal.

3. Memiliki peningkatan ketrampilan dalam pengembangan kreassi seni tari nusantara

4. Binaan dalam masyarakat dapat meningkatkan ekonomi keluarga sehingga memperoleh kesejahteraan yang lebih baik, terutama tidak menggantungkan hidupnya kepada orang lain, karena memiliki kepercayaan diri, dan ketrampilannya dapat mendatangkan penghasilan.

Dengan memilki bekal keahlian ketrampilan Seni Tari para peserta pelatihan Pengabdian Masyarakat ini dapat menciptakan lapangan pekerjaan sendiri. Dengan keahlian ketrampilan bidang seni tari, hasil dari kegiatan pelaksanaan pengabdian pada masyarakat yaitu keahlian ketrampilan tari, maka peserta dapat menciptakan lapangan kerja sendiri, yaitu dengan kemampuan menari bisa membuat sanggar -sanggar tari sendiri serta juga bisa menjadi seniman penari yang bisa dikontrak untuk pentas baik dalam acara formal maupun non formal. Bila dibina secara terus menerus diharapkan akan membantu program pemerintah dalam mengentaskan pendidikan serta kemiskinan, Sehingga terwujud kesejahteraan masyarakat.

\section{KEPUSTAKAAN}

Akhadiat Karta Miharja (1961) Seni dalam Pembinaan Kepribadian Nasional, Budaya, Z/1-2 Djauhari- Februari

De witt H. Parker tt. Dasar-Dasar Estetika. Terjemahan SD. Humardani. Surakarta: Akademi Seni Karawitan Indonesia

Pamadhi, Hajar. (2008). Pendidikan Seni di SD, Jakarta.

Hartoko, Dick (1983) Manusia dan Seni. Kanisius, Yogyakarta.

Sudarsono (1977) Estetika. Yogyakarta

Sedyawati, Edy. 2004. Pertumbuhan Seni Pertunjukan. Jakarta: Sinar Harapan. 1984/ 2006. Tari.

Tinjauan dari
berbagai segi..
Jakarta: Pustaka Jaya
1986. Pengetahuan Elementer Tari dan Beberapa 
ISSN: 1979-0953 | e-ISSN: 2598-6066

masalah tari. Jakarta

: Depdikbud.

Suanda Sumaryano Endo, 2006. Tari

Tontonan, Jakarta:

lembaga Pendidikan

Seni Nusantara.

Susanto Astrid. 1993. "Sejarah Kesenian

Tari Dan Musik “

Seminar, Jakarta :

Pustaka Sinar

Harapan.

Soedarsono. 1978. Pengantar Komposisi dan

Pengetahuan Tari.

Yogyakarta: ASTI.

The Liang Gie. (1976) Garis Besar Estetik, Super Sucses, Yogyakarta

Tim Penyusun.
1989

Pakaian

Adat

Tradisional Daerah

Propinsi Sulawesi Utara.

Sulawesi

Utara:

Depdikbud.

1979

Ensiklopedi Musik dan

Tari Daerah Sulawesi

Utara. Manado: Proyek

Penelitian dan

pencatatan kebudayaan

Daerah.

1993

Kumpulan Tari Daerah

Sulawesi Utara. Manado:

Taman Budaya

Propinsi Sulawesi Utara. 
Jurnal ABDIMAS, Vol. 12, No. 2, Agustus 2019

ISSN: 1979-0953 | e-ISSN: 2598-6066 